\title{
СОВРЕМЕННЫЕ АСПЕКТЫ И МЕХАНИЗМЫ ОБЕСПЕЧЕНИЯ УСТОЙЧИВОГО СТРАТЕГИЧЕСКОГО РАЗВИТИЯ ОТРАСЛЕЙ ПИЩЕВОЙ И ПЕРЕРАБАТЫВАЮЩЕЙ ПРОМЫШЛЕННОСТИ В МИРЕ И В РЕСПУБЛИКЕ БЕЛАРУСЬ
}

\begin{abstract}
А.В. Пилипук, С.А. Кондратенко*
В статье представлены результаты системного анализа тенденций развития пищевой и перерабатывающей промышленности в мире: актуальные направления развития отраслей, механизмы формирования и усиления конкурентных преимуществ ведущих экспортеров продовольствия. Дана оценка потенциала отечественной пищевой и перерабатывающей промышленности по показателям:-динамика производства и использования мощностей, инновационный потенциал, уровень конкурентоспособности продукции. Обоснованы ключевые факторы и направления устойчивого стратегического роста конкурентоспособности, включая наращивание производственно-экономического потенциала и его эффективное использование в условиях внутреннего и внешнего рынков.
\end{abstract}

Ключевые слова: мировой рынок, пищевая и перерабатывающая промышленность, стратегия, планирование, инновации, маркетинговые исследования, продвижение.

JEL-классификация: O13, Q13, Q18.

DOI: $10.46782 / 1818-4510-2020-2-79-95$

Материал поступил 20.04.2020 २.

В настоящее время пищевая промышленность Республики Беларусь в полной мере обеспечивает насыщение внутреннего рынка конечными продуктами питания высокого качества и эффективную реализацию экспортного потенциала национального АПК. Являясь основным потребителем сырья, промышленные предприятия объективно принимают на себя стимулирующую роль развития сельского хозяйства, совершенствования технологий, внедрения инноваций, повышения конкурентоспособности продукции, роста добавленной стоимости в продуктовых цепочках и интеграции национального АПК в мировую рыночную систему (Гусаков, Пилипук, 2018; Пилипук, Гусаков, Субоч, 2016; Пилипук, Колеснев, 2019). При этом на практике практически всегда можно проследить четкую зависимость эффективности и конкурентоспособности всей технологической цепи там, где перерабатывающее предприятие целенаправленно управляет развитием сырьевой зоны, вкладывая соответствующие инвестиции, знания и компетенции.

Вместе с тем в пищеперерабатывающей отрасли промышленности Беларуси к настоящему времени увеличивается влияние ряда деструктивных факторов, таких как давление ценовой конъюнктуры и мер тарифного и нетарифного регулирования на основных рынках сбыта, недостаточный инновационный потенциал товаропроизводителей и ограниченные возможности для инвестиций и др. Снижение их воздействия следует признать в качестве приоритетных задач устойчивости конкурентоспособности и динамичного развития всего АПК страны (Гусаков, Шпак, Киреенко, Кондратенко, 2018; Гусаков, Шпак, 2018; Киреенко, Кондратенко, Бречко, Горбатовский, 2019)1.

Ежегодно нарастает и усугубляется тенденция снижения конкурентоспособности

${ }^{1}$ Кондратенко С.А. 2019. Устойчивое развитие регионального агропродовольственного комплекса: теория, методология, практика. Минск: Институт системных исследований в АПК НАН Беларуси.

\footnotetext{
* Пилипук Андрей Владимирович (agrecinst@mail.belpak.by), доктор экономических наук, доцент, Институт системных исследований в АПК НАН Беларуси (г. Минск, Беларусь);

Кондратенко Светлана Александровна (kondratenko-0703@mail.ru), кандидат экономических наук, доцент, Институт системных исследований в АПК НАН Беларуси (г. Минск, Беларусь).
} 
отечественной продукции по доле продукции отечественных товаропроизводителей в структуре продаж организаций торговли в 2019 г. указанный показатель снизился на 2,1 п. п. и составил 77,5\%. При этом доля отечественного масла растительного сократилась на 5,3 п. п., мучных кондитерских изделий - 5,1, сахаристых кондитерских изделий - 8,3, сахара и его заменителей 8,3 , рыбы и продуктов из рыбы - 7,2, муки - 4,4, крупы - на 0,8 п. п.

Уровень стоимости и качество сельскохозяйственного сырья по ряду причин (агроклиматические, организационно-экономические, институциональные) не позволяют устойчиво поддерживать конкурентную себестоимость готовой продукции. Сохраняют актуальность проблемы ресурсного обеспечения сельского хозяйства: производство продукции растениеводства неустойчиво, уровень применения удобрений и средств защиты растений снижается, кормовая база животноводства остается несбалансированной и ограничивает потенциал продуктивности животных и др.

В этой связи важнейшее значение имеет оценка резервов эффективного использования ресурсов в отраслях растениеводства, животноводства, пищевой и перерабатывающей промышленности с целью выработки мер по оптимизации себестоимости с учетом ее конкурентного уровня.

С другой стороны, проблема также в том, что отечественные товаропроизводители не консолидируются, а единолично конкурируют на внутреннем и внешнем рынках с крупными зарубежными интегрированными компаниями, которые отличаются высоким уровнем инновационного и производственно-экономического потенциала, используют эффективные корпоративные системы управления бизнес-процессами, что позволяет им достигать оптимального уровня затрат в производстве и продвижении продукции.

Учитывая принимаемые меры по защите внутреннего рынка республики ${ }^{2}$, которые, безусловно, эффективны в краткосрочной перспективе, требуется обеспечить наращи-

2 Постановление Совета Министров Республики Беларусь от 30 марта 2020 г. № $184 \ll \mathrm{O}$ временных мерах по стабилизации ситуации на потребительском рынке»; Постановление Министерства антимонопольного регулирова- вание и реализацию стратегического потенциала устойчивого конкурентного развития продуктовых подкомплексов АПК, в том числе на основе формирования эффективных моделей взаимодействия субъектов. Для этого нами выполнен системный анализ мирового опыта и практики развития крупных компаний в области стратегического целеполагания и планирования производства, выявлены целевые критерии эффективности и конкурентоспособности. Такая систематизация мировой практики объективно может быть адаптирована в деятельности отечественных интегрированных формирований и отраслей при организации производства и бизнес-процессов, поиске и внедрении современных технологий продвижения инновационной продукции на внутреннем и внешнем рынках.

Теоретическую и методологическую основу исследования составили фундаментальные научные положения и прикладные отечественные и зарубежные разработки в сфере обеспечения устойчивого и сбалансированного развития пищевой и перерабатывающей промышленности. В ходе работы применялись монографический, расчетно-конструктивный, нормативный, методы системного и сравнительного анализа, а также экспертных оценок. Использовались официальные данные Национального статистического комитета Республики Беларусь.

\section{І. Глобальные тренды развития пи-} щевой промышленности рассмотрены нами по факторам, определяющим усиление конкуренции на мировом и внутреннем продовольственном рынках.

Во-первых, крупные интегрированные $u$ транснациональные компании стабильно занимают ведущие позищии на рынке готовых продуктов питания. Указанная тенденция подтверждается данными аналитического агентства Forbes. В рейтинге Top Regarded Companies за 2019 г. компания Kellogg на 13-м месте, объем продаж компании равняется 20,1 млрд долл. США, рыночная капитализация - 12,6 млрд долл. США, Kraft Heinz Company- на 17-м месте (20,2 и 40,2 млрд

ния и торговли Республики Беларусь от 25 сентября 2019 г. № 78 «Об установлении предельных минимальных цен на сахар белый кристаллический»; URL: http://www.pravo.by/ novosti/novosti-pravo-by/2020/mart/47726; URL: http:// www.pravo.by/upload/docs/op/W21934650_1569618000.pdf 
долл. США соответственно), General Mills на 40-м (14,7 и 31,0), Danone - на 100-м (20,8 и 51,0), Nestlé - на 118-м месте (92,6 и 281,3 млрд долл. США соответственно) (табл. 1).

При этом крупнейшие производители продуктов питания и напитков входят в число лидеров по стоимости и доходности корпоративных брендов World's Most Valuable Brands: Coca-Cola (6-е место), PepsiCo (29-e), Nestlé (50-e), Danone (76-е место), стоимость указанных брендов составляет 59,2, 18,8, 12,6 и 9,2 млрд долл. США соответственно.

Также указанные компании устойчиво инвестируют средства в НИР и внедрение инноваций. Так, среди мировых компаний лидеров инновационного развития эксперты выделяют Coca-Cola (53-е место в рейтинге), Mondelēz International (62-e), PepsiCo (67-e место), Kellogg (88-е место). Это позволяет устойчиво поддерживать значительную добавленную стоимость акций, уплачиваемую инвесторами за ожидаемый рост доходности компании, которая составляет 42,7, 41,7, 40,7 и $36,6 \%$ соответственно.

Исследования подтверждают, что успешная коммерциализация инновационных продуктов и услуг, внедрение инновационных технологий производства и бизнес-моделей являются ключевыми драйверами стратегического развития в отрасли. Так, по данным экспертов Innobarometer около 79\% производителей, внедривших хотя бы одно новшество, за четыре года увеличивают свой оборот более чем на $25 \%{ }^{3}$. С учетом практики развития организаций пищевой промышленности в Европейском союзе и США нами выделены следующие актуальные направления инновационной деятельности ${ }^{4}$ (de Velde, Rammer, Padilla, Schliessler, Slivko, Gehrke, Bilsen, Lukach, 2012; Vallin, 2016):

- поддержание трендов «продовольственной революции» ${ }^{5}$. Включает развитие товаров и услуг, соответствующих принци-

3 URL: https://ec.europa.eu/growth/industry/ innovation en

${ }^{4}$ Top 10 Trends 2017 by Innova Market Insights. 2017. Food Tech Summit \& Expo. URL: https://www.enfasis.com/ Presentaciones/FTSMX/2017/Summit_Food_Tech/FRIDA_

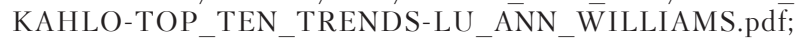
URL: https://www.clustercollaboration.eu/eu-initiatives/reports/ vision-european-industry-until-2030; URL: https://aak.com/ applications/chocolate-and-confectionery/spreads; URL: https:/ /www.cspdailynews.com/snacks-candy/mondelez-unveils-newsnacking-innovation-hub; URL: https://www.ams.usda.gov/sites/ default/files/media/Assessing\%20Alternative $\% 20$ Food\% 20Distribution\%20Models.pdf

${ }^{5}$ URL: https://www.foodrevolutionsummit.org

Таблица 1

Глобальный рейтинг производителей и ритейла продуктов питания и напитков, Top Regarded Companies, сентябрь 2019 г.

\begin{tabular}{|c|c|c|c|c|c|c|c|}
\hline \multirow[b]{2}{*}{ Место } & \multirow[b]{2}{*}{ Компания, страна } & \multirow{2}{*}{$\begin{array}{c}\text { Рыночная } \\
\text { капитализация } \\
\text { компании, } \\
2018 \text { г., млрд долл. } \\
\text { США } \\
\end{array}$} & \multirow[b]{2}{*}{$\begin{array}{c}\text { Численность } \\
\text { работников, } \\
2018 \text { г., } \\
\text { тыс. чел. } \\
\end{array}$} & \multicolumn{2}{|c|}{ Выручка, млрд долл. США } & \multicolumn{2}{|c|}{ Рентабельность продаж, \% } \\
\hline & & & & 2018 г. & $\begin{array}{c}\text { изменение } \\
\text { 2016-2018 гг., } \\
\text { П. П. }\end{array}$ & 2018 г. & $\begin{array}{c}\text { изменение } \\
\text { 2016-2018 гг., } \\
\text { П. П. } \\
\end{array}$ \\
\hline \multicolumn{8}{|c|}{ Производители продуктов питания и напитков } \\
\hline 13 & Kellogg, США & 20,1 & 34,0 & 12,6 & 95,5 & 9,5 & 0,4 \\
\hline 17 & Kraft Heinz Company, США & 40,2 & 41,0 & 20,2 & 77,1 & 3,0 & $-39,4$ \\
\hline 32 & Coca-Cola, США & 203,0 & 62,6 & 31,1 & 66,5 & 21,9 & 3,5 \\
\hline 34 & PepsiCo, США & 178,2 & 267,0 & 43,2 & 65,0 & 13,7 & 4,1 \\
\hline 40 & General Mills, США & 31,0 & 40,0 & 14,7 & 98,7 & 8,8 & $-3,3$ \\
\hline 100 & Danone, Франция & 51,0 & 105,78 & 20,8 & 77,3 & 9,1 & 0,5 \\
\hline 118 & Nestlé, Швейцария & 281,3 & 308,0 & 92,6 & 98,2 & 9,2 & $-2,1$ \\
\hline 123 & Almarai, Саудовская Аравия & 15,4 & 38,0 & 1,6 & 76,2 & 18,3 & 3,8 \\
\hline 161 & Grupo Bimbo, Мексика & 10,1 & 138,0 & 8,6 & 80,4 & 5,1 & 1,4 \\
\hline 182 & McCormick, США & 20,4 & 11,6 & 3,2 & 86,5 & 9,4 & $-0,7$ \\
\hline 183 & Inner Mongolia Yili, Китай & 27,9 & 59,1 & 3,6 & 62,1 & 26,4 & 21,6 \\
\hline 193 & Lotte, Южная Корея & 3,2 & Н. Д. & 2,1 & 31,8 & 19,8 & - \\
\hline 195 & Hershey, США & 23,7 & 16,4 & 5,3 & 86,9 & 8,2 & $-2,1$ \\
\hline 206 & Lindt \& Sprungli, Швейцария & 18,6 & 14,5 & 2,3 & 82,1 & 7,7 & $-2,2$ \\
\hline \multicolumn{8}{|c|}{ Ритейл продуктов питания } \\
\hline 80 & Tesco, Великобритания & 31,9 & 445,3 & 90,2 & 88,3 & 4,1 & $-0,8$ \\
\hline 95 & Carrefour, Франция & 14,7 & 363,9 & 121,5 & 111,6 & 0,4 & 2,6 \\
\hline 107 & $\begin{array}{l}\text { Companhia Brasileira de } \\
\text { Distribuicao, Бразилия } \\
\end{array}$ & 6,3 & н. Д. & 11,6 & 41,7 & 2,8 & 1,3 \\
\hline 219 & Yonghui Superstores, Китай & 13,0 & 92,1 & 6,6 & 71,0 & 2,0 & $-0,9$ \\
\hline 233 & Kroger, США & 20,6 & 453,0 & 76,6 & 84,7 & 0,1 & $-0,6$ \\
\hline 247 & CP All, Тайланд & 21,7 & Н. Д. & 3,3 & 60,0 & 4,8 & 0,1 \\
\hline
\end{tabular}

Источник. Данные рейтингового агентства Forbes. 
пам здорового и сбалансированного питания: повышение доступности пищевых продуктов высокого качества, обеспечение безопасности продовольствия, поддержка потребителей в улучшении питания и здоровья;

- своевременная разработка и внедрение стандартов качества и безопасности сырья и продовольствия в рамках всей технологической цепочки;

- динамичное и непрерывное внедрение инновационных продуктов и бизнес-моделей, обеспечивающих рост добавленной стоимости, создание новых рабочих мест, содействие процветанию городских и сельских сообществ;

- углубленная цифровая трансформация пищевой промышленности с ориентацией на комплексное выстраивание интегрированных интеллектуальных и экологически устойчивых продовольственных систем (производство сырья, переработка, распределение, логистика, потребление);

- циркулярность и продвижение энерго- и ресурсосберегающих технологий, снижающих нагрузку на окружающую среду, потери продуктов и сельскохозяйственного сырья, обеспечивающих сохранение культурного и биоразнообразия, природных ресурсов, поддержание и рост благополучия.

Углубленный анализ стратегий и результатов деятельности ведущих мировых компаний, таких как Nestlé, Danone и Kellogg позволил выявить важнейшие факторы их эффективного роста (табл. 2).

Стратегии развития компаний основываются на устойчивой системе корпоративных ценностей и целей продовольственной безопасности, включая: улучшение качества жизни и создание здорового будущего; использование традиций и преимуществ местных производителей, создание ценных брендов, которым доверяют потребители; осуществление исследований и разработок в целях создания и внедрения инновационных инициатив, корпоративная ответственность и устойчивость.

Следует также отметить ключевые используемые механизмы и меры, среди которых:

ускоренные инновации и быстрый вывод новых продуктов, которые используются как инструмент стимулирования роста и обеспечения устойчивости в нестабильной внешней среде и возрастающем ценовом давлении. Компании активно применяют стимулирующие стартапы в области инновационных пищевых технологий;

предоставление персонализированных услуг и продуктов на основе цифровых интеллектуализированных моделей продвижения;

\section{Ключевые положения стратегий некоторых ведущих мировых производителей} продуктов питания, 2019 г.

\begin{tabular}{|c|c|c|c|c|}
\hline Компания & Сущность стратегии & Ключевые задачи & Показатели & Механизмы \\
\hline Nestlé & $\begin{array}{l}\text { Устойчивая система } \\
\text { ценностей, ориентированная } \\
\text { на улучшение качества } \\
\text { жизни и создание здорового } \\
\text { будущего. } \\
\text { Привлекательный портфель } \\
\text { продуктов в растущих } \\
\text { категориях с лидирующими } \\
\text { позициями на рынке. } \\
\text { Использование местных } \\
\text { традиций, ценные бренды, } \\
\text { которым доверяют } \\
\text { потребители. } \\
\text { Лучшие в отрасли } \\
\text { возможности исследований } \\
\text { и разработок для } \\
\text { поддержания стратегии в } \\
\text { области питания и } \\
\text { инновационных инициатив }\end{array}$ & $\begin{array}{l}\text { Увеличение доходности за } \\
\text { счет инноваций, диффе- } \\
\text { ренциации и соответствия } \\
\text { требованиям потребителей. } \\
\text { Повышение операционной } \\
\text { эффективности с целью } \\
\text { роста рентабельности } \\
\text { продаж до } 17,5-18,5 \% \text { (с } \\
16,0 \% \text { в } 2016 \text { г.). } \\
\text { Перераспределение } \\
\text { ресурсов и капитала в } \\
\text { соответствии с ключевыми } \\
\text { приоритетами, в том числе } \\
\text { путем приобретений и } \\
\text { продажи активов }\end{array}$ & $\begin{array}{l}\text { Рост продаж продукции } \\
\text { за период 2015-2018 гг. - } \\
103,0 \% \text { (до 91,4 млрд } \\
\text { швейцарских франков), } \\
\text { базовой операционной - } \\
\text { прибыли } 116,0 \% \text { (до } 15,5 \\
\text { млрд). } \\
\text { Инвестированный } \\
\text { капитал в 2018 г. 32,2 } \\
\text { млрд швейцарских } \\
\text { франков. } \\
\text { Расходы на маркетинг и } \\
\text { административные } \\
\text { расходы - 21,9\% от } \\
\text { выручки в 2018 г. } \\
\text { Расходы на исследования } \\
\text { и разработки 1,7 млрд } \\
\text { швейцарских франков, } \\
\text { или 1,8\% от выручки. } \\
\text { В 2018 г. } 10 \% \text { контактов } \\
\text { с потребителями } \\
\text { персонализированы, } \\
\text { электронные продажи } \\
\text { достигли 7,4\%. } \\
\text { Централизовано 55\% } \\
\text { закупок, прогноз } \\
\text { на 2020 г. - 60\% }\end{array}$ & $\begin{array}{l}\text { Ускоренные инновации и } \\
\text { быстрый вывод новых } \\
\text { продуктов на рынок. } \\
\text { Цифровое преобразование, } \\
\text { направленное на } \\
\text { предоставление } \\
\text { персонализированных услуг и } \\
\text { продуктов. } \\
\text { Модернизация брендов и } \\
\text { бизнес-операций, внедрение } \\
\text { новых бизнес-моделей на } \\
\text { основе цифровых технологий. } \\
\text { Экономия в сфере закупок за } \\
\text { счет эффекта масштаба с } \\
\text { использованием трех } \\
\text { глобальных центров. } \\
\text { Углубление специализации, и } \\
\text { увеличение загрузки } \\
\text { мощностей. } \\
\text { Рост эффективности } \\
\text { исследований, разработок и } \\
\text { маркетинга. } \\
\text { Высвобождение ресурсов для } \\
\text { роста и инноваций за счет } \\
\text { сокращения оборотного } \\
\text { капитала }\end{array}$ \\
\hline
\end{tabular}


Современные аспекты и механизмы обеспечения устойчивого стратегического развития отраслей

Окончание табл. 2

\begin{tabular}{|c|c|c|c|c|}
\hline Компания & Сущность стратегии & Ключевые задачи & Показатели & Механизмы \\
\hline Danone & $\begin{array}{l}\text { Эффективный и устойчивый } \\
\text { рост на основе постоянного } \\
\text { внедрения инноваций и } \\
\text { включения в } \\
\text { «продовольственную } \\
\text { революцию», направленную } \\
\text { на здоровое питание. } \\
\text { Постоянное расширение и } \\
\text { использование глубоких } \\
\text { знаний компании в науке, а } \\
\text { также об особенностях } \\
\text { региональных рынков и } \\
\text { потребностях в области } \\
\text { питания. } \\
\text { Постоянное повышение } \\
\text { качества продуктов и } \\
\text { совершенствование } \\
\text { маркировки. } \\
\text { Ускоренное включение в } \\
\text { глобальные тренды } \\
\text { перехода к циркулярной } \\
\text { экономике }\end{array}$ & $\begin{array}{l}\text { Обеспечение информиро- } \\
\text { ванного потребительского } \\
\text { выбора и множества } \\
\text { здоровых альтернатив. } \\
\text { Полное раскрытие рецептур } \\
\text { и ингредиентов продукции. } \\
\text { Внедрение } 100 \% \text { упаковки } \\
\text { свежей молочной продукции, } \\
\text { одобренной ВОЗ, вторично } \\
\text { применяемой или полностью } \\
\text { компостируемой к } 2025 \text { г. } \\
\text { Ответственное финансиро- } \\
\text { вание и увеличение текущей } \\
\text { прибыли на акцию до } 3,56 \\
\text { евро или на } 12,8 \% \text { к } \\
\text { достигнутому уровню. } \\
\text { Обеспечение устойчивого } \\
\text { роста добавленной стои- } \\
\text { мости всех участников } \\
\text { продовольственной цепочки } \\
\text { (здоровой атмосферы и } \\
\text { устойчивого будущего). } \\
\text { Повышение уровня образо- } \\
\text { вания в области здорового } \\
\text { питания в школах в Европе } \\
\text { и развивающихся регионах } \\
\text { (100 000 учашихся и } 20 \text { 000 } \\
\text { родителей) }\end{array}$ & $\begin{array}{l}\text { В 2018-2019 гг. более } \\
89 \% \text { продаж осущест- } \\
\text { влялись в категориях } \\
\text { здорового питания. } \\
87 \% \text { упаковки подлежит } \\
\text { вторичной переработке } \\
\text { или является биоразла- } \\
\text { гаемой. } \\
\text { Устойчивая операцион- } \\
\text { ная доходность на } \\
\text { уровне } 14,5 \% \\
\text { Рост продаж в } 2018 \text { г. } \\
102,3 \% \text { по отношению к } \\
\text { предыдущему. } \\
\text { Инновационная продук- } \\
\text { ция составляет более } \\
\text { 25\% продаж, по срав- } \\
\text { нению с } 16 \% \text { в } 2016 \text { г. } \\
\text { Скорость вывода иннова- } \\
\text { ционных продуктов уве- } \\
\text { личилась на } 40 \% \text { благо- } \\
\text { даря продуманному ди- } \\
\text { зайну, быстрому прото- } \\
\text { типированию и привле- } \\
\text { чению торговых парт- } \\
\text { неров и потребителей. } \\
\text { Ускоренный рост } \\
\text { электронных продаж } \\
\text { (прирост более } 40 \% \text { за } \\
\text { 2018 г.) }\end{array}$ & $\begin{array}{l}\text { Инновации как инструмент } \\
\text { стимулирования роста и } \\
\text { обеспечения устойчивости в } \\
\text { нестабильной внешней среде } \\
\text { при возрастающем ценовом } \\
\text { давлении. } \\
\text { Применение цифровых } \\
\text { технологий в продвижении } \\
\text { инноваций и продуктов. } \\
\text { Персонифицированный } \\
\text { маркетинг, обеспечивающий } \\
\text { высокую эффективность } \\
\text { взаимодействия с } \\
\text { потребителем. } \\
\text { Инновационные программы } \\
\text { вовлечения сотрудников в } \\
\text { процесс управления бизнесом. } \\
\text { Совместная работа по } \\
\text { дорожным картам } \\
\text { инновационного развития, } \\
\text { формирование мышления } \\
\text { ответственности. Начиная с } \\
\text { 2019 г., каждому сотруднику } \\
\text { предоставлена одна акция } \\
\text { Dапопе в сочетании с } \\
\text { усиленной системой } \\
\text { поощрения на основе } \\
\text { дивидендов. } \\
\text { Стимулирующие стартапы в } \\
\text { области пищевых технологий. } \\
\text { Рациональное распределение } \\
\text { капитала }\end{array}$ \\
\hline Kellogg & $\begin{array}{l}\text { Процветание на основе } \\
\text { создания продуктов пита- } \\
\text { ния и брендов высокого } \\
\text { качества. } \\
\text { Корпоративная ответствен- } \\
\text { ность и устойчивость, } \\
\text { содействие обеспечению } \\
\text { глобальной продовольствен- } \\
\text { ной безопасности и дости- } \\
\text { жению ЦУР }\end{array}$ & $\begin{array}{l}\text { Повышение эффективности } \\
\text { собственного производства } \\
\text { в целях выполнения } \\
\text { глобальных обязательств в } \\
\text { области ЦУР. } \\
\text { Преодоление } \\
\text { дополнительных расходов, } \\
\text { связанных с существенной } \\
\text { суммой задолженности } \\
\text { компании по отношению к } \\
\text { собственному капиталу. } \\
\text { Устранение рисков, связан - } \\
\text { ных с задолженностью, } \\
\text { включая: } \\
\text { ухудшение доступа к гло- } \\
\text { бальным рынкам капитала; } \\
\text { понижение кредитных рей- } \\
\text { тингов и ограничения по } \\
\text { выпуску ценных бумаг для } \\
\text { покрытия дополнительных } \\
\text { затрат; } \\
\text { ограничение гибкости в } \\
\text { реагировании на } \\
\text { коньюнктуру финансовых и } \\
\text { товарных рынков. } \\
\text { Упреждение рисков, прису - } \\
\text { щих многонациональным } \\
\text { операциям, в том числе: } \\
\text { потеря управления опера- } \\
\text { циями на определенных } \\
\text { рынках и деконсолидация } \\
\text { компании; } \\
\text { введение новых торговых } \\
\text { барьеров и ценового регу- } \\
\text { лирования, изменение госу- } \\
\text { дарственной валютной } \\
\text { политики и др. }\end{array}$ & $\begin{array}{l}\text { Kellogg является гло- } \\
\text { бальной компанией и } \\
\text { генерировала 40\% } \\
\text { в } 2018 \text { г. и } 42 \% \text { в } 2018 \text { г. } \\
\text { доходов за пределами } \\
\text { США. } \\
\text { Расходы на исследования } \\
\text { и разработки в } 2018 \text { г. } \\
\text { составили 154, в } 2019 \text { г. - } \\
144 \text { млн долл. США. } \\
\text { Операционная прибыль } \\
\text { по отношению к чистым } \\
\text { продажам составила } \\
12,6 \% \text { в 2018 г. и 10,3\% в } \\
2019 \text { г. } \\
\text { Балансовая стоимость } \\
\text { нематериальных активов } \\
\text { на конец 2018 г. - 9,4 } \\
\text { млрд долл. США, из } \\
\text { которых 6,1 млрд - } \\
\text { гудвилл, 3,3 млрд - } \\
\text { торговые марки, } \\
\text { названия и прочие } \\
\text { приобретенные } \\
\text { нематериальные активы. } \\
\text { Совокупная стоимость } \\
\text { активов компании равна } \\
17,8 \text { млрд долл. }\end{array}$ & $\begin{array}{l}\text { Централизованное управление } \\
\text { всеми операциями и закупками. } \\
\text { Анализ эффективности } \\
\text { компании посредством } \\
\text { «чистых» индикаторов, } \\
\text { исключающих влияние } \\
\text { изменений валютных курсов, } \\
\text { времени отгрузки и других } \\
\text { непроизводительных факторов, } \\
\text { искажающих доходность } \\
\text { компании на конкретных } \\
\text { рынках и сегментах. } \\
\text { Индикаторы включают: } \\
\text { валютно-нейтральные и } \\
\text { скорректированные показатели } \\
\text { чистых продаж, операционной } \\
\text { прибыли, прибыли в расчете на } \\
\text { душу населения, валовой } \\
\text { маржи, денежного потока и др.; } \\
\text { показатели эффективности } \\
\text { конкретных мер и инициатив, } \\
\text { направленных на повышение } \\
\text { доходности; } \\
\text { мониторинг процесса } \\
\text { оптимизации глобальной } \\
\text { налоговой ставки компании }\end{array}$ \\
\hline
\end{tabular}

Источник. Авторская разработка по данным официальных сайтов и годовых отчетов компаний Nestlé, Danone, Kellogg.

модернизация брендов и бизнес-операций, внедрение новых бизнес-моделей на основе цифровых технологий; оптимизация затрат, экономия в сфере закупок и операционных расходов за счет специализации, использования эффекта мас- 
штаба и централизации управления. Такой подход позволяет обеспечить высвобождение ресурсов для роста и инноваций за счет сокращения оборотного капитала;

вовлечение сотрудников в процесс управления бизнесом, включая совместную работу по дорожным картам инновационного развития и формирование мышления ответственности;

использование объективных расчетных индикаторов для анализа эффективности деятельности компании и отдельных проектов, исключающих влияние непроизводительных факторов (изменения валютных курсов, времени отгрузки и др.).

Во-вторых, развитие обрабатывающих отраслей АПК целенаправленно регулируется во всех без исключения развитых странах. Имеет место координация на государственном и межстрановом уровнях, в том числе специализированными союзами, ассоциациями, технологическими платформами. Так, устойчивое развитие промышленности Европейского союза до 2030 г. предусматривает следующие меры (van de Velde, Romainville, Kroll, Wydra, Rammer, Izsak, Markianidou, Spaini, Collado, Sabanov, 2019; Bradley, Hill, 2015):

- достижение лидерства в технологиях, инновациях и устойчивом развитии. В качестве ключевого драйвера выделен растущий потребительский спрос на прозрачность и прослеживаемость, меняющий модели организации производства, коммерциализации добавленной стоимости продуктов с ориентацией на эффективное сочетание политики и инвестиционных стратегий, в том числе на основе государственночастного партнерства;

- прогнозирование и содействие развитию инноваций и компетенций в отраслях на основе внедрения и массового освоения междисциплинарных разработок на базе цифровых технологий, способствующих повышению производительности труда. Для этого ЕС планирует увеличить роль и число исследователей и преподавателей мирового уровня в развитии промышленности, расширить взаимодействие между исследованиями, образованием и бизнес-сектором. Цель - создать активы и компетенции, при помощи которых производители смогут улучшить свои ин- новационные возможности и конкурентоспособность, сформировать потенциал, необходимый для лидерства в мировых цепочках создания стоимости;

- концентрация усилий и капитала на стратегических цепочках создания стоимости, формирующих и развивающих сетевые и кластерные структуры. Европейская промышленность уже позиционирует свою результативность посредством целей и задач глобального устойчивого развития ЦУР, рассматривая их как конкурентные преимущества. Ведущие отрасли ориентированы на переход от управления цепочками поставок к управлению интегрированными индустриально-инновационными экосистемами, используя при этом региональные возможности и специализацию (кластерный подход). Поддержка и финансирование стратегических цепочек осуществляются инструментами Horizon 2020, Horizon Europe, InvestEU;

- создание благоприятной и гибкой конкурентной среды, обеспечивающей прозрачность, предсказуемость и последовательность промышленной и сельскохозяйственной политики, снижение рисков разработки и внедрения инновационных технологий и продуктов. В данной связи регулирующие органы ЕС отражают необходимость сохранения адекватной государственной поддержки формированию конкурентного потенциала товаропроизводителей в границах нормативно-правового регулирования ВТО, ОЭСР и международных правовых отношений.

В-третьих, ускоренно растет концентрация ресурсов и капитала в большинстве отраслей АПК в мире. Так, по данным IFCN Dairy, крупнейшими мировыми производителями молока сырого по итогам 2018-2019 гг. стали Almarai (Саудовская Аравия), которая производит более 1,47 млн т (молочное стадо составляет более 105,0 тыс.), Modern Dairy (Китай) - 1,28 млн т (134,3 тыс. гол.), Rockview (США) - 1,18 млн т (более 100,0 тыс. гол) ${ }^{6}$ и др. Среди крупнейших производителей российская компания EkoNiva - производит 0,80 млн т молока сырого, молочное стадо достигает 93,0 тыс. гол. Это быстрорастущая сельскохозяйственная компания, кото-

${ }^{6}$ URL: https://ifcndairy.org/ifcn-top-10-list-dairyfarming-companies-worldwide- 2020 
рая располагает потенциалом производства 1,0 млн т молока уже в 2020 г. (табл. 3). Исследование IFCN также подтверждает, что крупнотоварное производство превосходит мелкие фермы во всех аспектах устойчивости, включая экологический, социальный и экономический7.

Ключевая особенность - развитие эффективных моделей взаимоотношений между производителями молочного сырья и переработчиками, основанных на стратегическом партнерстве в целях повышения эффективности «вверх по цепочке поставок» ${ }^{8}$.

Высокий уровень концентрации прослеживается и среди производителей готовой продукции. Так, в Германии 3 компании производят 34\% общего объема молочной продукции, 5 компаний - 42\% и 10 - 57\%, в Нидерландах данное соотношение составляет 3 82,5 - 92, 10 - 98, в Новой Зеландии - 3 83, 5 - 86, 10 - 87, в Китае - 3 - 20, 5 - 22, 10 - 25\% соответственно. В целом 60 стран обеспечивают 90\% мирового рынка молочной продукции (de Velde, Rammer, Padilla, Schliessler, Slivko, Gehrke, Bilsen, Lukach, 2012).

Компания Dairy Farmers of America в год перерабатывает 29,7 млн т молока и создает 0,5 долл. США добавленной стоимости с 1 переработанного литра, у производителя Fonterra указанные индикаторы составляют - 23,7 и 0,6, Nestlé - 13,7 и 1,8, FrieslandCampina -13,6 и 1,0, Danone 8,6 млн т и 2,0 долл. США соответственно (табл. 4).

${ }^{7}$ URL: https://ifcndairy.org/ifcn-products-services/ifcnfarm-feeding-system-data

8 URL: https://ec.europa.eu/growth/sectors/food/ competitiveness/supply-chain-forum en
Показатели продуктивности молочного стада в США превышают 11,5 тыс. кг в год, в Германии - более 8 тыс. кг, в Новой Зеландии - более 5,5 тыс. кг, численность коров на одной ферме составляет - 500, 120 и 380 голов соответственно, расход кормов - 27, 18 и 15 кг сухого вещества на 1 молочную корову. Приведенные показатели достигаются, в первую очередь, за счет эффективной организации производства, применения энерго- и ресурсоэффективных технологий кормления и содержания животных, снабжения материально-техническими ресурсами и др. Следует отметить, что показатели эффективности использования ресурсов и производства молока, а также технологии организации производства являются частью информационно-аналитической системы IFCN D5.2, которая интегрирует данные по типовым фермам в 50 странах мира и позволяет использовать их сельхозпроизводителям, переработчикам и инвесторам для улучшения взаимоотношений в цепочке поставок.

Происходит ориентация на устойчивые долгосрочные отношения между производителями сельскохозяйственного сырья, перерабатывающими предприятиями и торговлей как фактор роста производительности и стоимости. При этом механизмы взаимодействия основываются как на применении добровольных долгосрочных контрактов, так и на создании крупных интегрированных формирований с различной формой кооперации производителей. Так, обязательные контракты между производителями молочного сырья и переработчиками охватывают 41\% поставок молока в 13 государствах - членах ЕС. Во

Крупнейшие мировые производители молока сырого, 2018-2019 гг.

Таблица 3

\begin{tabular}{|c|c|c|c|}
\hline \multicolumn{2}{|c|}{ По объему производства, млн т в год } & \multicolumn{2}{|c|}{ По численности молочного стада, тыс. гол. } \\
\hline Almarai & 1,47 & Modern Dairy & болеe 105,0 \\
\hline Modern Dairy & 1,28 & Almarai & болеe 100,0 \\
\hline Rockview & 1,18 & Rockview & около 100,0 \\
\hline Riveview & 1,00 & Huishan Dairy & около 95,0 \\
\hline Fara Brovers & 1,00 & Riveview & около 95,0 \\
\hline EkoNiva & 0,80 & Fara Brovers & 93,0 \\
\hline Huishan Dairy & 0,77 & EkoNiva & 72,8 \\
\hline Shengmu & 0,66 & Shengmu & 69,0 \\
\hline Saikexing & 0,62 & Saikexing & 55,0 \\
\hline Yilli Youran & 0,53 & Yilli Youran & \\
\hline
\end{tabular}

Источник. Данные IFCN Dairy. URL: https://ifcndairy.org/ 
Рейтинг мировых производителей молочной продукции IFCN Dairy

Таблица 4 и показатели их эффективности, 2018 г.

\begin{tabular}{|c|l|c|c|c|}
\hline $\begin{array}{c}\text { Место в } \\
\text { рейтинге }\end{array}$ & $\begin{array}{c}\text { Компания, страна } \\
\text { переработан- } \\
\text { ного молока, } \\
\text { млн т МЕ }\end{array}$ & $\begin{array}{c}\text { Добавленная стоимость, } \\
\text { созданная при } \\
\text { переработке одного кг } \\
\text { молока, долл. США }\end{array}$ & $\begin{array}{c}\text { Доля в мировом } \\
\text { производстве } \\
\text { молочной } \\
\text { продукции, \% }\end{array}$ \\
\hline 1 & Dairy Farmers of Аmerica, США & 29,2 & 0,5 & 3,5 \\
\hline 2 & Fonterra, Новая Зеландия & 23,7 & 0,6 & 2,8 \\
\hline 3 & Groupe Lactalis, Франция & 19,6 & 1,1 & 2,4 \\
\hline 4 & Arla Foods, Дания, Швеция & 13,9 & 0,8 & 1,7 \\
\hline 5 & Nestlé, Швейцария & 13,7 & 1,8 & 1,6 \\
\hline 6 & FrieslandСampina, Нидерланды & 13,6 & 1,0 & 1,6 \\
\hline 7 & Saputo (incl.MG), США, Канада & 9,8 & 1,1 & 1,2 \\
\hline 8 & Dean Foods, США & 9,4 & 0,8 & 1,1 \\
\hline 9 & Amul (GCMМF), Индия & 9,3 & 0,7 & 1,0 \\
\hline 10 & Danone, Франция & 8,6 & 2,0 & 1,0 \\
\hline 11 & DMK, Германия & 8,1 & 0,9 & 0,9 \\
\hline 12 & California Dairies, США & 7,7 & 0,5 & 0,9 \\
\hline 13 & Yili Group, Китай & 7,2 & 1,4 & 0,8 \\
\hline 14 & Glanbia Group, Ирландия, США & 6,5 & 0,6 & 0,8 \\
\hline 15 & Mengniu, Китай & 6,4 & 1,4 & 0,8 \\
\hline 16 & Agropur, Канада, США & 6,3 & 0,8 & 0,6 \\
\hline 17 & Groupe Sodiaal, Франция & 4,9 & 1,2 & 0,6 \\
\hline 18 & Müller, Германия & 4,6 & 1,1 & 0,5 \\
\hline 19 & Schreiber Foods, США & 4,5 & 1,1 & 0,5 \\
\hline 20 & Bongrain/Savencia, Франция & 4,1 & 1,3 & \\
\hline
\end{tabular}

Источник. Данные IFCN Dairy. URL: https://ifcndairy.org/

Франции минимальный срок контракта составляет 5 лет, в Италии, Испании и Словении - 1 год, в Венгрии, Португалии, Болгарии - 6 месяцев $^{9}$. Производители молока сырого имеют возможность согласовать условия контракта (включая цену) через объединения производителей. Объединения производителей в ЕС позволяют увеличить «рыночную силу» производителей сельскохозяйственной продукции за счет формирования более крупных партий, улучшить маркетинг в отраслях, обеспечить методическую и материально-техническую помощь, улучшить доступ к программному финансированию, в том числе в развитии собственной логистики (Fellmann, 2009). Из более чем 3400 объединений производителей по итогам 2018 г. $52 \%$ сосредоточены в производстве овощей и фруктов, 39\% - молока и молочных продуктов, $9 \%$ в других секторах ${ }^{10}$.

Основные цели объединения производителей молока и молочных продуктов

9 URL: https://ec.europa.eu/agriculture/milk/milkpackage/com-2016-724_en.pdf

${ }^{10}$ URL: https://ec.europa.eu/agriculture/sites/agriculture/ files/milk/milk-package/slide-show-implementation_en.pdf включают: обеспечение концентрации ресурсов - 85\%, продвижение продукции на рынок (прямые продажи) - 77, оптимизация затрат и повышение эффективности использования инвестиционных ресурсов 50, улучшение качества продукции - 48, планирование производства с учетом спроса - 45, стабилизация цен производителей - 28, внедрение высоких стандартов производства - 17, внедрение инновационных технологий и инициатив по развитию производства и рынка $-13 \%{ }^{11}$ и др.

Для достижения поставленных целей применяются следующие меры: проведение совместных переговоров - 66\%, выработка общих коммерческих стратегий - 60, планирование объемов производства - 49, планирование качества продукции - 43, организация контроля качества - 26, продвижение и транспортная логистика - 25, кооперация при использовании оборудования и хранилищ - 22 , переработке - 17 , упаковке - 16 , управлении отходами $-7 \%$.

11 URL: https://op.europa.eu/en/publication-detail/-/ publication/2c31a562-eef5-11e9-a32c-01aa75ed71a1 
Таким образом, проведенный анализ свидетельствует, что зарубежные товаропроизводители системно планируют и достигают конкурентных преимуществ на основе концентрации ресурсов и капитала до уровня обеспечивающего значимое влияние на рынок, увеличивают расходы на инновации и инвестиции за счет оптимизации операционных затрат, выстраивают устойчивые и взаимовыгодные отношения во всей продуктовой цепочке, даже в условиях, когда давление конъюнктуры рынков нарастает, а внешняя среда является крайне нестабильной.

II. Уровень и направления развития пищевой и перерабатывающей промыщленности Республики Беларусъ. Стратегические направления развития отечественной пищевой и перерабатывающей промышленности $^{12}$ в целом учитывают значимые тенденции мирового рынка и необходимость наращивания производственно-экономического потенциала, включая:

дальнейший рост промышленного производства на основе совершенствования применяемых технологий (ресурсосберега-

${ }^{12}$ URL: https://mshp.gov.by/programms/a868489390de 4373.html;URL: http://www.economy.gov.by/uploads/files/ NSUR2030/Natsionalnaja-strategija-ustojchivogo-sotsialno-ekono micheskogo-razvitija-Respubliki-Belarus-na-period-do-2030-goda.pdf ющих и безотходных), внедрения инноваций, снижения импортоемкости продукции;

повышение конкурентоспособности и эффективную реализацию экспортного потенциала отраслей пищевой промышленности;

обеспечение роста производительности труда по добавленной стоимости и других показателей эффективности в отраслях до уровня ЕC;

экологизацию производства сырья и готовой продукции путем внедрения «зеленых» технологий и оборудования и др.

За последние годы производство основных продуктов пищевой и перерабатывающей промышленности увеличилось. Так, за период 2011-2018 гг. темп роста производства мяса и пищевых субпродуктов составил $136,7 \%$, колбасных изделий - 96,5, рыбы и морепродуктов пищевых - 161,6, масла растительного - 212,3, цельномолочной продукции - 123,4, сыров (кроме плавленого) - 143,2, масла сливочного - 109,7\%, предварительные показатели за 2019 г. по отношению к предыдущему году составили $103,8,96,6,108,5,107,3,101,3,119,3$ и $100,8 \%$ соответственно (табл. 5). Индекс производства продуктов питания, напитков и табачных изделий в 2019 г. в сопоставимых ценах равен 102,1\%.

Таблица 5

Производство отдельных видов промышленной продукции в натуральном выражении, тыс. т

\begin{tabular}{|l|c|c|c|c|c|c|}
\hline \multirow{2}{*}{ Вид продукции } & \multicolumn{5}{|c|}{ Год } & Темп роста \\
\cline { 2 - 6 } & 2011 & 2015 & 2016 & 2017 & 2018 & 2011-2018 гг,, \% \\
\hline Мясо и пищевые субпродукты & 830,4 & 1020,7 & 1059,4 & 1105,5 & 1135,1 & 136,7 \\
\hline Колбасные изделия & 289,8 & 266,0 & 275,5 & 279,5 & 279,8 & 96,5 \\
\hline $\begin{array}{l}\text { Полуфабрикаты мясные и мясосодержащие } \\
\text { (включая мясо птицы) }\end{array}$ & 168,1 & 156,2 & 156,1 & 177,4 & 217,7 & 129,5 \\
\hline $\begin{array}{l}\text { Рыба и морепродукты пищевые, включая } \\
\text { рыбные консервы }\end{array}$ & 70,8 & 98,5 & 92,0 & 101,0 & 114,4 & 161,6 \\
\hline Масло сливочное и пасты молочные & 104,3 & 113,6 & 117,9 & 120,0 & 114,4 & 109,7 \\
\hline $\begin{array}{l}\text { Цельномолочная продукция (в пересчете на } \\
\text { молоко) }\end{array}$ & 1643 & 1963 & 1972 & 2000,8 & 2027,3 & 123,4 \\
\hline Сыры (кроме плавленого) & 141,9 & 180,8 & 191,4 & 193,4 & 203,2 & 143,2 \\
\hline Мука & 737,3 & 617,4 & 801,6 & 714,8 & 608,8 & 82,6 \\
\hline Крахмалы, кроме модифицированного & 17,0 & 15,3 & 21,4 & 16,5 & 16,9 & 99,4 \\
\hline Макаронные изделия & 38,0 & 39,2 & 44,0 & 41,3 & 40,0 & 105,3 \\
\hline Продукты готовые для детского питания & 17,1 & 20,9 & 21,2 & 24,4 & 28,8 & 168,4 \\
\hline Растительные масла & 181,7 & 262,1 & 149,2 & 169,9 & 385,7 & 212,3 \\
\hline Шоколад, кондитерские изделия из сахара & 71,5 & 60,0 & 63,4 & 71,4 & 72,8 & 101,8 \\
\hline $\begin{array}{l}\text { Корма готовые для сельскохозяйственных } \\
\text { животных }\end{array}$ & 5861,6 & 6268,7 & 6307,1 & 6317,4 & 6180,9 & 105,4 \\
\hline
\end{tabular}

Источник. Данные Национального статистического комитета Республики Беларусь. 
По основным видам продукции обрабатывающей промышленности наблюдается прирост производственных мощностей, что требует соответствующего наращивания объема производства сельскохозяйственного сырья необходимого качества и ассортимента. В среднем за период 2015-2017 гг. коэффициент использования мощностей предприятий по производству мяса составил $71,4 \%$, мясу птицы - 87,4, колбасным изделиям - 72,3, маслу сливочному $-73,4$, молоку и сливкам сухим - 83,5, сырам твердым - 87,2, муке - 84,7, крупе $-61,1$, саха- ру белому свекловичному - 98,8, мясным консервам для детского питания - 35,5, плодоовощным и фруктовым консервам для детского питания - 68,9, маслам растительным - 45,5\% (табл. 6).

Объем отгруженной инновационной продукции в 2019 г. на предприятиях по производству продуктов питания, напитков и табачных изделий остается невысоким и составляет 683,4 млн руб. или 3,4\% к общему объему (2,9\% в 2018 г.). В том числе по видам экономической деятельности (по данным 2017 г.) удельный вес инновационной про-

Таблица 6

\section{Наличие и уровень загрузки производственных мощностей по основным видам продукции обрабатывающей промышленности}

\begin{tabular}{|c|c|c|c|c|c|}
\hline \multirow[b]{2}{*}{ Наименование } & \multirow{2}{*}{$\begin{array}{c}\text { Изменение } \\
\text { балансовой } \\
\text { мощности за } \\
\text { 2015-2017 гг., \% }\end{array}$} & \multicolumn{3}{|c|}{ Использование, \% } & \multirow{2}{*}{$\begin{array}{c}\text { Средний за } \\
\text { 2015-2017 гг. }\end{array}$} \\
\hline & & 2015 г. & 2016 г. & 2017 г. & \\
\hline Мясо & 139,6 & 73,3 & 71,0 & 69,9 & 71,4 \\
\hline Мясо птицы & 176,7 & 89,6 & 89,0 & 83,6 & 87,4 \\
\hline Колбасные изделия & 116,0 & 72,7 & 73,7 & 70,6 & 72,3 \\
\hline Консервы мясные & 107,1 & 33,1 & 41,4 & 41,9 & 38,8 \\
\hline Рыба и морепродукты, консервы & 120,1 & 37,3 & 38,8 & 44,9 & 40,3 \\
\hline Молоко и сливки сухие & 92,3 & 86,5 & 82,5 & 81,6 & 83,5 \\
\hline Масло сливочное и пасты молочные & 104,2 & 73,6 & 75,6 & 71,0 & 73,4 \\
\hline Творог и творожные изделия & 115,2 & 80,7 & 73,2 & 71,2 & 75,0 \\
\hline $\begin{array}{l}\text { Цельномолочная продукция (в пересчете на } \\
\text { молоко) }\end{array}$ & 4568 & 72,5 & 72,4 & 66,5 & 70,5 \\
\hline Сыры твердые (кроме плавленого) & 106,4 & 88,0 & 88,3 & 85,2 & 87,2 \\
\hline Мука & 100,1 & 76,6 & 91,3 & 86,3 & 84,7 \\
\hline Крупа & 105,2 & 59,5 & 63,5 & 60,3 & 61,1 \\
\hline Крахмалы (кроме модифицированных) & 88,6 & 45,7 & 43,5 & 34,1 & 41,1 \\
\hline Хлеб и хлебобулочные изделия & 89,6 & 50,5 & 51,1 & 54,6 & 52,1 \\
\hline Мучные кондитерские изделия & 103,5 & 64,9 & 64,6 & 66,9 & 65,5 \\
\hline $\begin{array}{l}\text { Изделия макаронные и аналогичные } \\
\text { изделия мучные }\end{array}$ & 97,4 & 81,2 & 90,0 & 84,8 & 85,3 \\
\hline Сахар белый свекловичный & 104,5 & 98,0 & 98,5 & 99,9 & 98,8 \\
\hline $\begin{array}{l}\text { Шоколад, изделия кондитерские из } \\
\text { шоколада и сахара }\end{array}$ & 101,7 & 58,8 & 59,2 & 61,4 & 59,8 \\
\hline $\begin{array}{l}\text { Питание детское на молочной основе } \\
\text { жидкое или пастообразное }\end{array}$ & 100,0 & 56,6 & 79,9 & 90,6 & 75,7 \\
\hline Питание детское на молочной основе сухое & 100,0 & 93,6 & 87,8 & н. д. & 90,7 \\
\hline $\begin{array}{l}\text { Консервы для детского питания мясные, } \\
\text { мясосодержащие }\end{array}$ & 100,0 & 37,5 & 35,8 & 33,1 & 35,5 \\
\hline $\begin{array}{l}\text { Консервы для детского питания } \\
\text { плодоовощные и фруктовые }\end{array}$ & 30,9 & 54,5 & 71,4 & 80,8 & 68,9 \\
\hline Соки для детского питания & 71,4 & 57,2 & 83,3 & 88,0 & 76,2 \\
\hline $\begin{array}{l}\text { Плодоовощные консервы (кроме детского } \\
\text { питания) }\end{array}$ & 106,1 & 44,6 & 41,9 & 42,7 & 43,1 \\
\hline $\begin{array}{l}\text { Соки фруктовые и овощные (кроме } \\
\text { детского питания) }\end{array}$ & 104,9 & 34,8 & 29,1 & 29,8 & 31,2 \\
\hline Масла растительные & 75,0 & 48,4 & 38,3 & 49,7 & 45,5 \\
\hline
\end{tabular}

Источник. Данные Национального статистического комитета Республики Беларусь. 
дукции (в общем объеме) на предприятиях по переработке и консервированию мяса и производству мясной и мясосодержащей продукции был равен 2,6\%, переработке и консервированию рыбы - 9,7, переработке и консервированию фруктов и овощей - 1,3, производству растительных и животных жиров и масел - 1,2, молочных продуктов - 3,4, крахмала и продуктов из крахмала - 2,8 , хлебобулочных и мучных кондитерских изделий не длительного хранения - 5,7, какао, шоколада и сахаристых кондитерских изделий - 15,9, детского питания и диетических пищевых продуктов - 14,2, готовых кормов для животных - 0,1\%.

Динамика инвестиций в основной капитал предприятий обрабатывающей промышленности характеризуется неустойчивыми темпами: в 2015 г. темп роста составил $84,6 \%$, 2016 г. $-61,2,2017$ г. $-102,0,2018$ г. $-116,0 \%$.

Удельный вес инновационно активных организаций в общем числе по данным 2018 г. достиг 20,3\%. При этом в структуре затрат на технологические инновации на приобретение машин и оборудования затрачено $77,2 \%$ средств, производственное проектирование 21,3 , маркетинговые исследования - 1,0 , исследования и разработки - $0,2 \%$.

На протяжении нескольких лет наблюдается сокращение доли отечественных про- дуктов питания в розничной торговле. В 2019 г. доля отечественных мучных кондитерских изделий на внутреннем рынке составила 70,6\%, сахаристых кондитерских изделий - 50,6, рыбы и продуктов из рыбы $45,5 \%$, муки - 85,7\%, крупы - 40,5, масла растительного - 12,0\%, в 2015 г. данный показатель был значительно выше - 79,6, 67,4, 55,5, $95,0,53,4$ и 28,4\% соответственно (табл. 7).

Указанная тенденция определяется рядом факторов. Во-первых, отечественное аграрное производство по объективным причинам не имеет относительных стоимостных преимуществ, обусловленных природно-климатическими и социально-экономическими условиями. Например, по сравнению с наиболее развитыми странами в Беларуси значительно ниже возможности государственной поддержки, высокая стоимость кредитных ресурсов, более низкий уровень цен и доходы населения, ограничены возможности защиты внутреннего рынка и др. При этом основные торговые партнеры республики более активно наращивают конкурентные преимущества и инновационный потенциал сельского хозяйства и пищевой промышленности $^{13}$. Во-вторых, уровень и динамика реальных денежных доходов населения респуб-

${ }^{13}$ URL: http://www.consultant.ru/document/cons_doc_ LAW_283022

Доля продукции отечественных товаропроизводителей в структуре продаж организаций торговли на внутреннем рынке республики, \%

\begin{tabular}{|c|c|c|c|c|c|c|c|}
\hline Продукты & 2016 г. & 2017 г. & 2018 г. & 2019 г. & $\begin{array}{c}\text { Изменение, } \\
2016- \\
2019 \text { гг., } \\
\text { п. п. }\end{array}$ & $\begin{array}{c}\text { Изменение, } \\
2018- \\
2019 \text { гг., } \\
\text { п. п. }\end{array}$ & $\begin{array}{c}\text { Изменение } \\
\text { объема продаж } \\
\text { в натуральном } \\
\text { выражении, } \\
2018-2019 \text { гг., } \\
\text { п. п. } \\
\end{array}$ \\
\hline Продовольственные товары & 81,3 & 80,8 & 79,6 & 77,5 & $-3,8$ & $-2,1$ & - \\
\hline Мясо и мясные продукты & 98,9 & 99,4 & 99,5 & 99,7 & 0,8 & 0,2 & $-4,3$ \\
\hline Сыры & 91,1 & 91,1 & 90,5 & 92,6 & 1,5 & 2,1 & 4,2 \\
\hline Рыба и продукты из рыбы & 55,5 & 52,0 & 52,7 & 45,5 & -10 & $-7,2$ & 1,8 \\
\hline $\begin{array}{l}\text { Мучные кондитерские } \\
\text { изделия }\end{array}$ & 79,6 & 79,4 & 75,7 & 70,6 & -9 & $-5,1$ & 8,1 \\
\hline $\begin{array}{l}\text { Сахаристые кондитерские } \\
\text { изделия }\end{array}$ & 67,4 & 67,2 & 58,9 & 50,6 & $-16,8$ & $-8,3$ & 9,1 \\
\hline Детское питание & 63,9 & 65,6 & 63,5 & 67,6 & 3,7 & 4,1 & 7,4 \\
\hline Крупа & 53,4 & 50,6 & 41,3 & 40,5 & $-12,9$ & $-0,8$ & $-2,3$ \\
\hline Мука & 95,0 & 93,5 & 90,1 & 85,7 & $-9,3$ & $-4,4$ & $-5,2$ \\
\hline Макаронные изделия & 62,4 & 61,4 & 54,6 & 64,2 & 1,8 & 9,6 & 0,7 \\
\hline Масло растительное & 28,4 & 20,6 & 17,3 & 12,0 & $-16,4$ & $-5,3$ & $-1,8$ \\
\hline Сахар и его заменители & - & 85,1 & 93,7 & 85,4 & 0,3 & $-8,3$ & $-12,4$ \\
\hline
\end{tabular}

Источник. Данные Национального статистического комитета Республики Беларусь. 
лики остаются недостаточными для развития внутреннего рынка. В сложившихся условиях отечественные товаропроизводители не имеют возможности в полной мере реализовать конкурентный потенциал, так как для основной массы потребителей при приобретении товаров в розничной торговле решающим фактором потребительского выбора становится более низкая цена импортных продовольственных товаров. Параметры качества часто не принимаются во внимание.

Отрасли пищевой и перерабатывающей промышленности устойчиво сохраняют высокий экспортный потенциал. Сальдо внешней торговли сельскохозяйственной продукцией и продуктами питания в 2018 г. достигло 855,7 млн долл. США. Темп роста экспорта мяса и субпродуктов в натуральном выражении за период 2016-2018 гг. составил 118,1\%, колбасных изделий - 141,8, масла сливочного - 101,7, сыров и творога 115,7 , фруктов замороженных - 126,1, продуктов из рыбы - 148,0, сахара - 117,8, шоколада и прочих готовых пищевых продуктов, содержащих какао -189,6, хлеба и мучных кондитерских изделий - 119,9\% (табл. 8).

Эффективность экспорта отечественных продуктов питания находится под давлением конъюнктуры внешнего рынка, что не позволяет в полной мере реализовать производственный потенциал. Так, темп роста экспорта шоколада и кондитерских изделий из шоколада (код ТН ВЭД 1806) за 2019 г. (январь-декабрь) по отношению к аналогичному периоду прошлого года в натуральном выражении составил 109,2\%, в стоимостном выражении - 116,3, 2018 г. - 111,1 и 101,2, 2017 г. - 135,2 и 148,2\%; кондитерских изделий из сахара (код ТН ВЭД 1704): за 2019 г. - 107,9 и 101\%, 2018 г. - 101,6 и $107,9 \%, 2017$ г. - 123,8 и 128,2\%; готовой и консервированной рыбы (код ТН ВЭД 1604): за 2019 г. - 109,6 и 109,7\%, 2018 г. 118,1 и 113,2\%, 2017 г. - 117,7 и 131,0\%; сыров и творога (код ТН ВЭД 0406): за 2019 г. - 115,5 и 122,7\%, 2018 г. - 111,5 и 101,6\%, 2017 г. - 92,1 и 115,7\%; масла сливочного (код ТН ВЭД 0405): за 2019 г. - 87,5 и $107,8 \%, 2018$ г. - 111,8 и 93,4\%, 2017 г. 94,1 и $129,8 \%$ соответственно.

Наиболее характерно влияние конъюнктуры внешнего рынка на конкурентоспособность отечественной продукции проявляется при осуществлении продаж через Белорусскую универсальную товарную биржу (БУТБ).

Стоимостная структура реализации продукции через БУТБ за январь-сентябрь 2019 г. имела следующий вид: шроты масличных (внутренний рынок, импорт) $26,03 \%$, злаковые и кормовые добавки, средства защиты растений (внутренний рынок, импорт) - 23,63, молочные продукты (внутренний рынок) - 20,61, молочные продукты (экспорт) - 16,12, растительные масла и

Таблица 8

Экспорт основных продуктов питания по видам, тыс. т

\begin{tabular}{|l|c|c|c|c|c|}
\hline \multicolumn{1}{|c|}{ Продукты } & 2015 г. & 2016 г. & 2017 г. & 2018 г. & $\begin{array}{c}\text { Tемп роста, } \\
\text { 2016-2018 гг., \% }\end{array}$ \\
\hline Мясо и мясные субпродукты & 281,5 & 311,3 & 304,5 & 332,5 & 118,1 \\
\hline Колбасы и аналогичные продукты из мяса & 26,8 & 37,0 & 42,1 & 38,0 & 141,8 \\
\hline Мясо и пищевые субпродукты домашней птицы & 136,3 & 145,9 & 150,4 & 166,5 & 122,2 \\
\hline Молоко и сливки, несгущенные & 324,9 & 316,9 & 307,1 & 245,5 & 75,6 \\
\hline Молоко и сливки, сгущенные и сухие & 234,3 & 212,9 & 230,7 & 215,1 & 91,8 \\
\hline Масло сливочное & 87,9 & 85,0 & 80,0 & 89,4 & 101,7 \\
\hline Сыры и творог & 182,5 & 205,0 & 189,4 & 211,2 & 115,7 \\
\hline Фрукты замороженные & 49,9 & 63,0 & 55,1 & 62,9 & 126,1 \\
\hline Масло рапсовое & 132,7 & 40,5 & 62,2 & 233,1 & 175,7 \\
\hline Готовая или консервированная рыба, икра & 34,8 & 37,1 & 43,6 & 51,5 & 148,0 \\
\hline Сахар & 362,8 & 351,6 & 407,1 & 427,2 & 117,8 \\
\hline $\begin{array}{l}\text { Шоколад и прочие готовые пищевые продукты, } \\
\text { содержащие какао }\end{array}$ & 12,5 & 15,8 & 21,3 & 23,7 & 189,6 \\
\hline Хлеб и мучные кондитерские изделия & 20,6 & 22,7 & 25,0 & 24,7 & 119,9 \\
\hline
\end{tabular}

Источник. Данные Национального статистического комитета Республики Беларусь. 
семена масличных (внутренний рынок, импорт) - 4,77, мясо (внутренний рынок, импорт) - 3,98, продукция переработки масличных культур (экспорт) - 2,92, мука, крупа (экспорт) - 1,09, мясо (экспорт) 0,49 , молоко коровье сырое (внутренний рынок) - 0,36, кожевенное сырье (экспорт) - 0,01\% (табл. 9).

Биржевой индекс цен экспорта молочной продукции характеризуется положительной динамикой, которая могла быть выше в условиях роста цен на рынке России. Вместе с тем, индекс биржевых цен на сухое обезжиренное молоко (базовый уровень февраль 2013 г.) составил в январе $1,03 \%$, апреле $-1,25$, сентябре $-1,27 \%$; на масло сливочное $(72,5 \%)-2,32,2,50$ и $2,58 \%$; на масло сливочное (82,5\%) - 2,44, 2,71 и $2,78 \%$ соответственно.

В настоящее время в целях недопущения необоснованного занижения стоимости молочной продукции по сравнению с реальными рыночными ценами введен ме- ханизм ценового коридора (в соответствии со ст. 17 Закона Республики Беларусь «О товарных биржах»).

Важно также отметить, что в последние годы биржа используется как канал альтернативных поставок молока сырого. Так, по итогам торгов молоком коровьим сырым с 9 апреля по 30 сентября 2019 г. в результате 21 торговой сессии БУТБ заключено 30 сделок объемом 3 тыс. т на сумму 2,46 млн белорусских рублей. В торгах принимали участие 11 производителей молока сырого и 22 перерабатывающих предприятия. Торги характеризовались выраженной конкуренцией покупателей, в результате чего продавцы получили дополнительную выручку за счет роста цен равную 80 тыс. рублей. При этом регламент биржевых торгов учитывает качество молока при формировании скидок и надбавок к цене.

Эффективность использования биржевого канала для продажи сельскохозяйственной и продовольственной продукции оцени-

Таблица 9

Объемы реализации продукции на Белорусской универсальной товарной бирже, 2015-2019 гг.

\begin{tabular}{|l|c|c|c|c|c|c|c|c|}
\hline \multirow{2}{*}{ Вид продукции } & \multicolumn{7}{|c|}{ Объем реализации, тыс. т } & \multicolumn{2}{c|}{$\begin{array}{c}\text { Стоимость } \\
\text { сделок, млн руб. }\end{array}$} \\
\cline { 2 - 9 } & 2015 г. & 2016 г. & 2017 г. & 2018 г. & $\begin{array}{c}2019 \text { г. } \\
\text { январь- } \\
\text { сентябрь })\end{array}$ & 2016 г. & 2018 г. \\
\hline \multicolumn{7}{|c|}{ Экспорт } \\
\cline { 2 - 9 }
\end{tabular}

Источник. Данные ОАО «Белорусская универсальная товарная биржа». URL: http://old.butb.by/ 
вается экспертами БУТБ посредством суммарного показателя дополнительной выручки продавцов и сэкономленными средствами покупателей. Расчет формируется за счет разницы между ценой начала торгов и ценой сделок. Так, указанная сумма за январьсентябрь 2019 г. составила 3,96 млн руб., в 2018 г. $-9,05,2017$ г. $-15,26,2016$ г. $-12,34$, 2015 г. - 25,10 млн руб.

Предприятия пищевой промышленности в настоящий момент в значительной степени заинтересованы в расширении применения механизма биржевых торгов при реализации и закупках продукции. В данной связи объективно предположить, что расширение использования электронной торговой площадки и логистической системы БУТБ позволит повысить эффективность закупок и продаж отечественных предприятий, диверсифицировать экспортные поставки, осваивать новые высокодоходные рынки ${ }^{14}$.

На основе проведенного анализа тенденций развития пищевой и перерабатывающей промышленности в мире и в Республике Беларусь выявлены следующие группы факторов, которые в перспективе будут определять устойчивость развития отрасли.

Факторы внешней среды:

сохранится значительное влияние конъюнктуры внешнего рынка на эффективность функционирования отечественных товаропроизводителей;

действующий в мире уровень государственной поддержки национальных товаропроизводителей и применение мер тарифной и нетарифной защиты на большинстве экспортных рынков в целом является основным ограничивающим фактором диверсификации поставок отечественного продовольствия;

продолжится ускоренное наращивание инновационного потенциала крупных транснациональных компаний, в том числе на внутреннем рынке Беларуси и рынках ЕАЭС в основном за счет существенно более высокой концентрации ресурсов;

в средне- и долгосрочной перспективе усилятся тенденции конкуренции на сырь-

14 URL: https://primepress.by/news/kompanii/ belgospishcheprom_gotov_rasshiryat_primenenie_birzhevogo_ mekhanizma_butb_pri_realizatsii_i_zakupkakh-17828/ евых рынках вследствие роста дефицита сельскохозяйственного сырья и ингредиентов высокого качества и др.

Конкурентные преимущества отечественных товаропроизводителей:

наличие значимого научно-технологического и инновационного потенциала отраслей пищевой и перерабатывающей промышленности, а также собственной индустрии здорового питания;

сохранение положительного имиджа белорусских продовольственных товаров как продуктов высокого качества (натуральные ингредиенты, устойчивое производство, использование местного сырья и др.);

устойчивые уровень самообеспечения и доступности по большинству видов сельскохозяйственного сырья и продовольствия, соответствующий количественным критериям продовольственной безопасности;

значительный экспортный потенциал белорусской продукции на рынке ЕАЭС, СНГ, а также системная работа по продуктовой и страновой диверсификации рынков сбыта и др.

Риски снижения устойчивости и конкурентоспособности отрасли:

сокращение ценовых преимуществ конкурентоспособности отечественной продукции вследствие объективных ограничений снижения себестоимости сырья и готовой продукции;

увеличение доли импортных продовольственных товаров на внутреннем рынке, которое может в дальнейшем привести к сокращению производственного потенциала отечественных товаропроизводителей и возникновению угроз продовольственной безопасности;

снижение покупательной способности населения, что не позволит отечественным товаропроизводителям реализовать конкурентный потенциал продукции высокого качества на внутреннем рынке;

давление коммерческой политики торговых сетей, при которой применяемые торговая наценка и условия поставок нивелируют конкурентные преимущества отечественных производителей (в особенности, малых и средних предприятий) на внутреннем и внешнем рынках; 
недостаточная инновационная и инвестиционная активность товаропроизводителей, которая не позволит динамично и непрерывно наращивать технологический потенциал в цепочке создания стоимости продукции;

ограниченные возможности осуществления маркетинговых исследований и разработок;

отсутствие механизмов государственного регулирования доходов отечественных экспортеров в условиях неблагоприятного влияния конъюнктуры (интервенционные закупки и продажи, государственная поддержка частного хранения, масштабное финансирование программ продвижения на внутреннем и внешнем рынках);

межотраслевая несбалансированность, связанная с непропорциональным применением мер ценового регулирования (в сахарной, кондитерской и других отраслях) и др.

Возможности по наращиванию конкурентного потенциала:

реализация резервов роста производства сельскохозяйственного сырья и продовольствия, повышение производительности ресурсов и эффективности;

своевременная и всеобъемлющая разработка и внедрение высоких стандартов качества и безопасности производства и продукции;

разработка и ускоренное освоение инновационных технологий, продукций и бизнес-моделей на белорусских предприятиях и объединениях, обеспечивающих рост добавленной стоимости в продуктовых цепочках;

реализация консолидированных стратегий развития отраслей пищевой и перерабатывающей промышленности, ориентированных на наращивание конкурентного потенциала товаропроизводителей на инновационной основе;

формирование эффективных моделей взаимодействия сельского хозяйства, обрабатывающей промышленности и сферы торговли, обеспечивающих наращивание и максимальную реализацию конкурентных преимуществ и др.

C учетом выявленных тенденций и глубокой научной проработки в Республике Беларусь в настоящее время вырабатывается комплекс мер и механизмов, обес- печивающих наращивание и эффективную реализацию конкурентного потенциала отраслей АПК, включая:

разработку и принятие стратегий устойчивого развития отраслей АПК на инновационной основе, учитывающих опыт мировых лидеров в производстве сырья и продуктов питания. При этом на уровне отраслевых ведомств и объединений производителей целесообразно внедрение современных методик экономической оценки технологических и продуктовых инноваций, механизмов ускоренного вывода и продвижения новых продуктов и технологий на рынок;

применение научно-практических рекомендаций по повышению эффективности сырьевой базы агропромышленного производства на основе интенсификации, совершенствования специализации и размещения отраслей, в том числе формированию сырьевых 3он;

ускоренное внедрение современного информационно-аналитического обеспечения деятельности отечественных производителей на внутреннем и внешнем рынках, включая подготовку оперативных прогнозов и обзоров развития отраслей и конъюнктуры товарных и сырьевых рынков (основные производители, импортеры, цены, объемы производства);

содействие повсеместному внедрению современных систем обеспечения безопасности и качества продукции отечественных производителей в соответствии с международной практикой прослеживаемости «от поля до стола». В том числе с использованием современных цифровых технологий подтверждения безопасности и качества белорусской продукции, обеспечивающих эффективное включение в интегрированный мировой рынок товаров;

стимулирование и развитие эффективного потребительского спроса на продукты питания, в том числе продукты питания высокого качества. Направление включает реализацию программ обеспечения молочными продуктами и местными овощами и фруктами в школах, дошкольных учреждениях образования, специальных учреждениях;

внедрение индикаторов экономической безопасности по критической доле им- 
портных товаров на внутреннем рынке республики для чувствительных товарных групп, увязанных с параметрами конкурентной среды отраслей, прогнозами потребительского спроса и целевыми критериями производства сельскохозяйственной продукции, сырья и продовольствия;

создание и реализацию механизмов государственного регулирования сбалансированности экспортоориентированных товарных рынков (сахар, молочная продукция), включая элементы государственных интервенционных закупок и продаж, оказание государственной поддержки хранения запасов и др.;

инвестирование в развитие современной инфраструктуры сбыта и продвижения продукции агропромышленного комплекса, ориентированной на максимальную реализацию конкурентных преимуществ отечественных товаропроизводителей на этапе оптовой и розничной торговли. В данной связи актуальными являются два направления развития сбытовой инфраструктуры. Первое - создание отечественной цифровой платформы для электронной торговли продуктами питания (оптовой и розничной), включая мобильное приложение для розничных покупателей с информацией о принципах здорового питания, безопасности и качестве продукции, ассортименте местных товаропроизводителей и возможностью формировать заказ на доставку. Второе направление - создание оптовых распределительных центров по торговле скоропортящейся продукцией с современными цифровыми технологиями товародвижения. Развитие в указанном направлении является приоритетным для торговых партнеров республики в ЕАЭС, которые активно ведут разработки по созданию цифровых продовольственных оптово-распределительных центров и платформ взаимодействия товаропроизводителей, потребителей, инвесторов и др.

Представленные в исследовании тенденции и направления развития обрабатывающей отрасли АПК отражают комплекс первоочередных мер и инструментов, реализация которых в ближайшей перспективе позволит направленно расширять использование производственного потенциала сельского хозяйства и обрабатывающей промышленности на инновационной основе, усиливать конкурентные преимущества товаропроизводителей на внутреннем и внешнем рынках, продолжить формирование устойчивых и эффективных цепочек создания высокой добавленной стоимости на основе интеграции в евразийскую и мировую рыночные системы.

\section{СПИСОК ЛИТЕРАТУРЫ (REFERENCES)}

Гусаков В.Г., Пилипук А.В. 2018. Конкурентоустойчивое развитие производства продуктов здорового питания в предприятиях пищевой промышленности. Минск: Беларуская навука. 367 c. [Gusakov V.G., Pilipuk A.V. 2018. Competitive sustainable development of the production of healthy food in food industry enterprises. Minsk: Belaruskaya navuka. 367 p. (In Russ.)]

Гусаков В.Г., Шпак А.П. 2018. Приоритетные направления повышения эффективности, конкурентоспособности и устойчивости развития аграрной отрасли. Весиі Нацыянальнай акадэміi навук Беларусі. Серыя аграрных навук. № 4. C. 401-409. [Gusakov V.G., Shpak A.P. 2018. Priority areas for improving the efficiency, competitiveness and sustainability of agricultural sector development. Vestsi Natsyyanal'nay akademii navuk Belarusi. Seryya agrarnykh navuk. No 4. PP. 401-409. (In Russ.)]

Гусаков В.Г., Шпак А.П., Киреенко Н.В., Кондратенко С.А. 2018. Условия и факторы реализации Доктрины национальной продовольственной безопасности Республики Беларусь до 2030 года. Весиі Нацыьянальнай акадэміі навук Беларусі. Серыя аграрных навук. Т. 56. № 3. С. 263-285. [Gusakov V.G., Shpak A.P., Kireyenka N.V., Kandratsenka S.A. 2018. Conditions and factors of implementing the Doctrine for National Food Security in the Republic of Belarus by 2030. Vestsi Natsyyanal'nay akademii navuk Belarusi. Seryya agrarnykh navuk. Vol. 56. No 3. PP. 263-285. (In Russ.)]

Киреенко Н.В., Кондратенко С.А., Бречко Я.Н., Горбатовский А.В. 2019. Актуальные тенденции и перспективные направления развития отраслей АПК Республики Беларусь. Белорусский экономический журнал. № 2. C. 87-100. [Kireyenka N.V., Kandratsenka S.A., Brechko Ya., Gorbatovski A.V. 2019. Current trends and promising directions of development of agricultural sectors of the Republic of Belarus. Belorusskiy ekonomicheskiy zhurnal. No 2. PP. 87-100. (In Russ.)]

Пилипук А.В., Гусаков Е.В., Субоч Ф.И. 2016. Институциональное пространство кластерной агропродовольственной системь Евразийского экономического союза: аспекты теории и практи- 
жи. Минск: Беларуская навука. [Pilipuk A.V., Gusakov V.G., Suboch F.I. 2016. The institutional space of the cluster agri-food system of the Eurasian Economic Union: aspects of theory and practice. Minsk: Belaruskaya navuka. (In Russ.)]

Пилипук А.В., Колеснев И.В. 2019. Методика оценки кластерного потенциала экспортно ориентированных предприятий пищевой промышленности Республики Беларусь. Весиі Нащьянальнай акадэміі навук Беларусі. Серыя аграрных навук. T. 57. № 4. C. 406-417. [Pilipuk A.V., Kolesnev I.V. 2019. Method for assessment of the cluster potential of export-oriented food industry enterprises in the Republic of Belarus. Vestsi Natsyyanal'nay akademii navuk Belarusi. Seryya agrarnykh navuk. Vol. 57. No 4. PP. 406-417. (In Russ.)]

Bradley D., Hill B. 2015. Cost of and good practices for FADN data collection. Final report. Luxembourg: Publications Office of the European Union. 160 p.

de Velde E., Rammer C., Padilla P., Schliessler P., Slivko O., Gehrke B., Bilsen V., Lukach R. 2012.
Exchange of good policy practices promoting the industrial uptake and deployment of Key Enabling Technologies. Brussels: IDEA Consult. 224 p.

Fellmann T. (Ed.). 2009. Regional Economic Analysis of Milk Quota Reform in the EU. Luxembourg: Office for Official Publications of the European Communities URL: https://publications.jrc.ec. europa.eu/repository/bitstream/JRC53116/jrc 53116.pdf

Vallin B. 2016. The competitive position of the European food and drink industry. Final report. Publications Office of the European Union. 168 p.

van de Velde E., Romainville J.-F., Kroll H., Wydra S., Rammer C., Izsak K., Markianidou P., Spaini C., Collado A., Sabanov I. 2019. Towards better monitoring of innovation strengths, regional specialisation and industrial modernisation in the EU. Luxembourg: Publications Office of the European Union. URL: https://op.europa.eu/en/publicationdetail/-/publication/8e2d2352-d5cf-11e9-883a01aa75ed71a1/language-en/format-PDF/source104843183

\title{
MODERN ASPECTS AND MECHANISMS FOR ENSURING SUSTAINABLE STRATEGIC DEVELOPMENT OF FOOD AND PROCESSING INDUSTRIES IN THE WORLD AND IN THE REPUBLIC OF BELARUS
}

\author{
Andrei Pilipuk ${ }^{1}$, Sviatlana Kandratsenka ${ }^{1}$ \\ Author affiliation: ${ }^{1}$ Institute for Systemic Research in AIC, National Academy of Sciences of Belarus \\ (Minsk, Belarus).
}

Corresponding author: Sviatlana Kandratsenka (kondratenko-0703@mail.ru).

ABSTRACT. The article presents the results of the systemic analysis of trends in the development of food and processing industries in the world: current trends of industry development, mechanisms of formation and enhancing competitive advantages of the leading food exporters. The potential of the domestic food and processing industries was assessed: the dynamics of production and utilization of capacities, innovative potential, and the products' competitiveness level. Substantiated are the key factors and directions for sustainable strategic competitiveness growth, including the enhancement of productive and economic capacity and its efficient application in the context of domestic and external markets.

KEYWORDS: global market, food and processing industry, strategy, planning, innovation, marketing research, promotion.

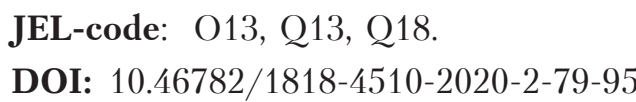

